\title{
Journal of Applied Ecology
}

MS LUCY ROSE MASON (Orcid ID : 0000-0001-9567-6262)

DR JENNIFER SMART (Orcid ID : 0000-0003-1789-4461)

Article type : Research Article

Editor : Richard Fuller

Are agri-environment schemes successful in delivering conservation grazing management on saltmarsh?

Lucy R. Mason ${ }^{1 *}$, Alastair Feather ${ }^{1}$, Nick Godden ${ }^{1}$, Chris C. Vreugdenhil ${ }^{1}$ \& Jennifer Smart ${ }^{1,2}$

${ }^{1}$ RSPB Centre for Conservation Science, RSPB, The Lodge, Sandy, Bedfordshire, SG19 2DL, UK.

${ }^{2}$ School of Biological Science, University of East Anglia, Norwich, NR4 7TJ, UK.

* Corresponding author: jennifer.smart@rspb.org.uk

Short title: Saltmarsh conservation grazing and agri-environment schemes

This article has been accepted for publication and undergone full peer review but has not been through the copyediting, typesetting, pagination and proofreading process, which may lead to differences between this version and the Version of Record. Please cite this article as doi: 10.1111/1365-2664.13405

This article is protected by copyright. All rights reserved. 


\section{Abstract}

1. Grasslands occur around the globe and, in temperate regions, their natural management by fire, drought and wild herbivores has largely been replaced by grazing with domestic livestock. Successful management for agriculture is not always suitable for conservation and can have a detrimental effect on biodiversity. Conservation grazing of saltmarshes, delivered through agri-environment schemes, may provide a solution to counteract biodiversity loss by providing farmers with financial incentives to graze these internationally important coastal wetlands more sensitively.

2. To assess whether conservation grazing is being achieved, and whether agrienvironment schemes are effective in delivering this management, we conducted a national survey on English saltmarshes, scoring the management on each site as optimal, suboptimal or detrimental in terms of suitability for achieving conservation aims for five aspects of grazing: presence, stock type, intensity, timing and habitat impact.

3. Although most saltmarshes suitable for grazing in England were grazed, conservation grazing was not being achieved. Sites under agri-environment management for longer did score higher and approached optimal levels in terms of grazing intensity in one region, but sites with agri-environment agreements were no more likely to be grazed at optimal conservation levels than sites without them overall, indicating that agri-environment schemes, in their current form, are an ineffective delivery mechanism for conservation grazing on saltmarsh.

4. The low specificity of agri-environment prescription wording may contribute to this failure, with prescriptions either being vague or specifying suboptimal or detrimental management objectives, particularly for grazing intensity, timing and stock type. These objectives are often set too high or too low, during unsuitable periods, or using stock types inappropriate for achieving conservation aims.

This article is protected by copyright. All rights reserved. 
5. Synthesis and applications. Our national survey indicates that agri-environment schemes are not currently delivering conservation grazing on English saltmarshes. Agri-environment schemes are the only mechanism through which such grazing can be implemented on a national scale, so improving their effectiveness is a priority. Policymakers, researchers and managers need to work together to ensure better translation of conservation guidelines into schemes, increasing the specificity of management prescriptions and improving understanding of the need for management measures. A more detailed and reliable system of auditing to ensure that management activities are taking place would be beneficial, or alternatively moving to a results-based scheme where payments are made on desirable outcomes rather than on evidence of management.

Keywords: countryside stewardship, higher level stewardship, livestock, site condition, agrienvironment schemes, saltmarsh, wetlands, grazing

\section{Introduction}

Maintaining and enhancing biodiversity through conservation action requires appropriate habitat management to ensure suitable conditions for the species or community of interest. Such management can encourage a return to a near-natural habitat state, encouraging restoration of ecosystem functioning and stability (Ausden 2007). Livestock grazing is an important tool used widely for conservation management across a wide range of grassland habitats, with livestock replacing the role of natural grazers where these have been lost (Ausden 2007). Grazing, both for conservation management and for food production, is a major driver of vegetation structure and therefore resource availability in natural systems

This article is protected by copyright. All rights reserved. 
globally (Watkinson \& Ormerod 2001) and can help to counteract the negative impacts of climate change (Clausen, Stjernholm \& Clausen 2013).

The restricted nature of livestock grazing for conservation management (such as lower stocking rates or timing restrictions) reduces its profitability relative to high-intensity farming, so uptake incentives are often provided to land managers in the form of payments for management through Agri-Environment Schemes (AES; Batáry et al. 2015). These are a key mechanism by which conservation grazing can be delivered at national levels. Targeted AES have been successful in delivering conservation management to benefit many wetland systems (e.g. Schekkerman, Teunissen \& Oosterveld 2008; Smart et al. 2014), but inadequate monitoring has made the overall assessment of AES effectiveness difficult (Kleijn \& Sutherland 2003)

Saltmarshes, that cover $~ 5.5$ million hectares of land surface globally (McOwen et al. 2017), are an example of a system traditionally managed by livestock grazing (cattle, sheep, horses; Dijkema 1990; Jones et al. 2011) for food production, and where AES are commonly used to encourage conservation management. Saltmarshes are highly productive ecosystems supporting rich communities of halophytic plants, invertebrates and birds through their provision of important resources and habitat conditions for bird breeding, wintering and migratory staging, as well as important fish nursery grounds, human recreational opportunities and ecosystem services in the form of tidal defence, water quality regulation and carbon storage (e.g. Boorman 2003; Barbier et al. 2011).

Over $50 \%$ of saltmarshes have been lost or degraded globally (UNEP 2006; Gedan, Silliman \& Bertness 2009), with the rate of degradation now exacerbated by climate change and 
associated sea level rise (Doody 2004; Hughes 2004; FitzGerald et al. 2008). In western Europe the biodiversity value of saltmarshes is declining despite protection under the EU Habitats and Water Framework Directives (Doody 2008; Garbutt et al. 2017; McOwen et al. 2017), with over $50 \%$ of the European coastal protected sites network now in 'unfavourable inadequate' or bad condition (European Environment Agency 2009). Agricultural intensification is a key factor in these biodiversity declines, with increases in grazing intensity or abandonment in recent decades resulting in declines in saltmarsh-breeding birds and plant and invertebrate community changes (Norris et al. 1998; Chatters 2004; Davidson et al. 2017).

Five aspects of grazing (termed 'conservation grazing') are particularly important for the conservation management of saltmarshes in western Europe: 1) whether sites should be grazed or not, 2) stock type, 3) grazing intensity, 4) timing of grazing and 5) the resulting habitat structure. Although recommendations for these five aspects vary between species or communities of interest (e.g. Davidson et al. 2017), the consensus from published and accessible grey literature (see Table S1 in Supporting Information) is that 'historicallygrazed' sites should continue to be grazed using cattle (Adnitt et al. 2007), in a mosaic or rotation of 'low' to 'moderate' grazing intensity (Doody 2007; Mandema et al. 2015; van Klink et al. 2016; Lagendijk et al. 2017) from April-October if targeting plant communities, or from June-October if targeting breeding birds (winter grazing November-March prevents optimal sward regrowth and causes soil compaction, poaching and erosion, while grazing in spring causes considerable bird nest losses to trampling; e.g. Adnitt et al. 2007; Doody 2008; Sharps et al. 2017). The resulting habitat should then present a mosaic of sward heights where the majority of standing crop is still present to support breeding birds and habitat diversity (JNCC 2004; Malpas et al. 2013).

This article is protected by copyright. All rights reserved. 
Despite these freely available conservation grazing recommendations (Adnitt et al. 2007; Doody 2008), many saltmarshes in western Europe are still grazed at suboptimal levels (Malpas et al. 2013). In England, 'input-based' AES systems (where payments are made based on the agreed management being undertaken; Hanley et al. 2012), have existed since 1991 and include saltmarsh management or grazing options where implementation relies on a list of management prescriptions. These schemes, and similar management on nature reserves, had little effect on grazing pressure on English saltmarsh and did not influence the associated decline in saltmarsh-breeding birds between 1996 and 2011, indicating they may not be delivering necessary habitat management or conservation outcomes (Malpas et al. 2013). There was therefore an urgent need to assess whether or not conservation grazing was being achieved on saltmarshes on a national scale, whether AES were effective in influencing this management and how they could be improved.

\section{Materials and methods}

\section{Study sites}

We surveyed 213 saltmarsh sites in three English regions in 2013 representing 50\% $(16,824$ ha) of the vegetated saltmarsh in England (33,572 ha; Phelan, Shaw \& Baylis 2011; Fig. 1). The regions (East, Northwest, South) represent major divisions between saltmarsh types and grazing practices (Burd 1989) and were managed by different statutory agency (Natural England) regional teams. Of our 213 study sites, 114 (54\%) received payments for saltmarsh management and/or conservation grazing options through AES under Higher Level Stewardship (HLS, in the Environmental Stewardship Scheme; Natural England 2013) or the Countryside Stewardship Scheme (CSS; DEFRA 2004; Fig. 1, Table 1, Table S2). These

This article is protected by copyright. All rights reserved. 
AES sites encompassed $94 \%$ (10,573 ha) of the vegetated saltmarsh under AES management in the three regions.

Outlines of UK Rural Land Registry land-holding parcels with saltmarsh management options for each AES agreement were used as site boundaries for AES sites. Most agreements $(n=99,87 \%)$ included one or more contiguous parcel(s) of saltmarsh habitat, all of which we defined as one site. For the few agreements $(n=7)$ that incorporated multiple non-contiguous parcels of saltmarsh, each parcel was considered a separate site because grazing management and management prescriptions may differ between geographically separate parcels, even within the same agreement (max no. separate parcels per agreement $=3$; total no. AES agreements $=106$ ). Non-AES site boundaries were hand-digitised with reference to Ordnance Survey 1:25,000 maps, online aerial imagery and seaward boundaries of predicted saltmarsh extent (Environment Agency 2015) in GIS (Maplnfo Professional v.6 2000). The area (ha) of each site was calculated using ArcGIS (version 10.3.1 2014).

Some sites comprised multiple grazing management blocks (hereafter 'grazing areas') separated by fencing or natural barriers to livestock movement, or formed part of larger grazing areas extending beyond site boundaries with livestock free to graze across the whole area (sometimes encompassing both saltmarsh and adjacent non-saltmarsh habitat). We therefore collected survey data at the grazing area scale to allow more-accurate assessment of conservation grazing per hectare of available grazing land associated with each site.

This article is protected by copyright. All rights reserved. 


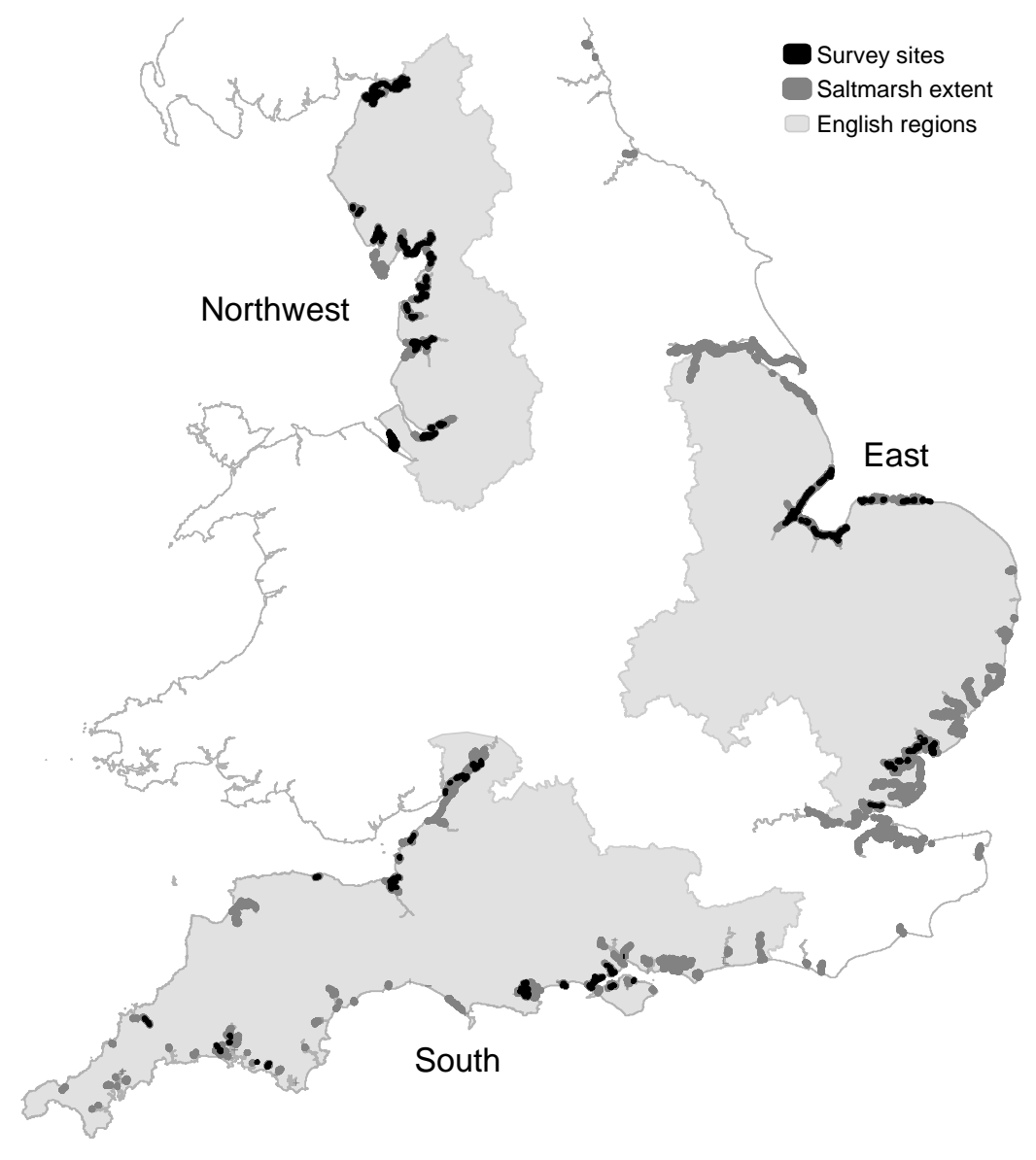

Figure 1. Locations of the 213 saltmarsh survey sites in relation to the distribution of saltmarsh within three English regions. For site types and spatial-pairings see Fig. S1.

This article is protected by copyright. All rights reserved. 
Table 1. Agri-environment scheme (AES) management options and supplements relating to saltmarsh management and/or conservation grazing present on AES sites, the number of sites with each option and annual payments per ha. CSS: Countryside Stewardship Scheme, HLS: Higher Level Stewardship.

\begin{tabular}{|c|c|c|c|c|}
\hline \multirow[b]{2}{*}{ AES } & \multicolumn{3}{|c|}{ Management option } & \multirow[b]{2}{*}{ \# Sites } \\
\hline & Code & Option & Payment & \\
\hline CSS & IT1 & Managing intertidal habitats & $£ 20$ & 8 \\
\hline HLS & HP5 & Maintenance of coastal saltmarsh & $£ 30$ & 82 \\
\hline & HP6 & Restoration of coastal saltmarsh & $£ 30$ & 14 \\
\hline & HP8 & Creation of inter-tidal and saline habitat on grassland & up to $£ 500$ & 2 \\
\hline & HP10 & Supplement for extensive grazing on saltmarsh & $£ 70$ & 36 \\
\hline & HP11 & Saltmarsh livestock exclusion supplement & $£ 40$ & 4 \\
\hline & HR1 & Grazing supplement for cattle & up to $£ 35$ & 16 \\
\hline
\end{tabular}

Is conservation grazing being achieved on English saltmarshes?

\section{Grazing surveys}

We visited each site up to four times during the core grazing period (April-October; mean no. survey visits to each site $=3.9$, grazed sites $=122,4$ visits $=113,3$ visits $=6,2$ visits $=$ 2,1 visit = 1), with at least four weeks between visits, and recorded the number, type, ageclass and distribution of livestock in each grazing area on each visit. We assumed that the absence of grazing animals in any survey visit meant the area was not being grazed at that time There is a small chance that livestock could be temporarily removed during spring high tides but in most sites, livestock had access to alternative areas not affected by tides (e.g. sea walls or inland fields) so would still be present and observable within the grazing area.

This article is protected by copyright. All rights reserved. 
Grazing intensities were expressed as Livestock Units (LUs) per hectare to allow direct comparison between stock types and sites. LUs were calculated from the number of adult livestock for each grazing area visit based on standard conversion coefficients (DEFRA 2010), where 1 LU is equivalent to 1 dairy cow, 9 lowland ewes and 0.8 horses respectively (Table S3). LUs/ha were calculated by summing the LUs recorded across all grazing areas per site visit, and dividing this total by the site area (ha).

We also assessed the longer-term impact of grazing on saltmarsh habitat in relation to the vegetation communities present (grazing alters the presence and diversity of saltmarsh plant communities, Hill 1988), and the sward height and heterogeneity by assigning each site or grazing area within sites a 'grazing index' value (Norris et al. 1998; Malpas et al. 2013). Here $0=$ matted vegetation, no standing crop removed, low ward heterogeneity; 1 = majority of standing crop not removed, high sward heterogeneity; 2 =majority of standing crop removed, moderate sward heterogeneity; 3 = all standing crop removed, sward height $<10 \mathrm{~cm}$, low sward heterogeneity (JNCC 2004). Although crude, this index gives a reasonable reflection of the habitat structure and grazing pressure (Norris et al. 1997).

\section{Scoring 'conservation grazing'}

For each visit to each grazing area, we used survey data to derive scores for five aspects of saltmarsh conservation grazing according to whether they represented optimal, suboptimal or detrimental saltmarsh management practices in relation to their suitability for achieving conservation aims (Table 2). These conservation grazing scores, derived at the grazing area scale for each visit, were summarised at the site-level using methods in Table 2 to allow analysis at the site-visit level (each row in the resulting score dataset corresponding to an individual site-visit).

This article is protected by copyright. All rights reserved. 
Table 2. Optimal, suboptimal and detrimental levels of five aspects of conservation grazing and the methods used to summarise across grazing areas to generate site-visit conservation grazing scores for each aspect, along with rationalisation and evidence sources.

\begin{tabular}{llll} 
& & \multicolumn{2}{c}{ Conservation grazing level and scoring criteria } \\
\cline { 3 - 4 } Aspect & Scoring method & Optimal $($ score $=1)$ & Detrimental $($ score $=0)$ \\
\hline$(1)$ & Sites suitable for grazing = directly accessible & Site SUITABLE and & Site SUITABLE and \\
Presen & from land, with infrastructure to contain & GRAZED & UNGRAZED \\
ce/ & livestock and drinking water. Grazed = grazing & or & or \\
Absenc & recorded in at least one grazing area per site- & Site UNSUITABLE and & Site UNSUITABLE and \\
e & visit. Binomial visit-level score $(0,1)$ & UNGRAZED & GRAZED
\end{tabular}

Rationalisation/Source: Historically-grazed sites should continue to be grazed at conservation levels (abandonment being detrimental to saltmarsh biodiversity) while historically-ungrazed sites should remain ungrazed (Adnitt et al. 2007). The true grazing history of a site in the UK is difficult to determine however, particularly if sites were abandoned outside of living or documented memory. For the purposes of this study we considered that sites classed as suitable for grazing during surveys (i.e. accessible to livestock and agricultural workers from the sea wall and surrounded by agricultural land) will most likely have been utilised for grazing historically (Chatters 2004).

\begin{tabular}{|c|c|c|c|c|}
\hline & & $\begin{array}{l}\text { Optimal (score } \\
=2 \text { ) }\end{array}$ & $\begin{array}{l}\text { Suboptimal (score = } \\
\text { 1) }\end{array}$ & $\begin{array}{l}\text { Detrimental } \\
(\text { score }=0)\end{array}$ \\
\hline (2) & Stock type categorised per grazing area per & CATTLE & SOME CATTLE & NO CATTLE \\
\hline Stock & visit as: Cattle, Sheep, Horses, Mixed with & GRAZING & GRAZING WITH & GRAZING or \\
\hline type & Cattle, Mixed without Cattle, or None (Table & ONLY & OTHER STOCK & NO STOCK \\
\hline & the combination of stock & Stock type $=$ & TYPES PRESENT & PRESENT \\
\hline & $\begin{array}{l}\text { type categories present across all grazing } \\
\text { areas per site-visit. Numeric visit-level score (0- } \\
\text { 2). }\end{array}$ & $\begin{array}{l}\text { Cattle in at } \\
\text { least one } \\
\text { grazing area; } \\
\text { no other stock } \\
\text { types recorded }\end{array}$ & $\begin{array}{l}\text { Stock type = Cattle or } \\
\text { Mixed with Cattle in } \\
\text { at least one grazing } \\
\text { area, in the presence } \\
\text { or absence of other } \\
\text { stock types. }\end{array}$ & $\begin{array}{l}\text { Stock type = } \\
\text { Sheep, Horse, } \\
\text { Mixed without } \\
\text { Cattle or None } \\
\text { in all grazing } \\
\text { areas }\end{array}$ \\
\hline $\begin{array}{l}\text { Ration } \\
\text { 2007). }\end{array}$ & on & ce veret & in sheep or horse & Adnitt et al. \\
\hline (3) & LUs calculated for each grazing area then & LOW & LOW-MODERATE & HIGH or NONE \\
\hline $\begin{array}{l}\text { Grazing } \\
\text { intensit } \\
\text { y }\end{array}$ & $\begin{array}{l}\text { summed across grazing areas for each site } \\
\text { visit. Score based on value of site-visit LUs/ha } \\
\text { (summed site-visit LUs divided by site area). }\end{array}$ & $\begin{array}{l}0<\text { LUs/ha } \leq \\
0.3\end{array}$ & $0.3<$ LUs/ha $\leq 0.7$ & $\begin{array}{l}\text { LUs/ha }>0.7 \text { or } \\
\text { LUs/ha }=0\end{array}$ \\
\hline
\end{tabular}

Numeric visit-level score (0-2).

Rationalisation/Source: Criteria based on mean maximum LUs/ha values classed as low, low-moderate or high by 26 sources where this information was quantified and accompanied by an assessment of suitability for conservation grazing (Table S1).

\begin{tabular}{|c|c|c|c|c|}
\hline $\begin{array}{l}\text { (4) } \\
\text { Timing } \\
\text { of } \\
\text { grazing }\end{array}$ & $\begin{array}{l}\text { Grazing areas scored for optimal grazing timing } \\
\text { for breeding birds and/or vegetation based on } \\
\text { the first and last visit grazing was recorded. } \\
\text { The minimum score from any grazing area per } \\
\text { site then extended across all visit to provide a } \\
\text { site-visit level score (accounting for the most } \\
\text { detrimental grazing period from any part of a } \\
\text { site). Numeric visit-level score (0-2). }\end{array}$ & $\begin{array}{l}\text { BIRDS = } \\
\text { Optimal } \\
\text { VEG }= \\
\text { Optimal }\end{array}$ & $\begin{array}{l}\text { BIRDS = Optimal, } \\
\text { VEG = Suboptimal } \\
\text { or } \\
\text { BIRDS = Suboptimal, } \\
\text { VEG = Optimal }\end{array}$ & $\begin{array}{l}\text { BIRDS }= \\
\text { Suboptimal } \\
\text { VEG }= \\
\text { Suboptimal }\end{array}$ \\
\hline \multicolumn{5}{|c|}{$\begin{array}{l}\text { Rationalisation/Source: BREEDING BIRDS: Optimal = grazing starts after the peak nesting period (end of May, i.e. } \\
\text { after visit 1), Suboptimal = grazing starts visit } 1 \text { (April - May). Grazing in the peak nesting period causes considerable } \\
\text { bird nest losses to trampling (Sharps et al. 2017). VEGETATION: Optimal = grazing April-October (grazing starts visit } 1 \\
\text { or later, ends before visit 4), Suboptimal = grazing continues after October (grazing still recorded visit 4). Winter grazing } \\
\text { after October prevents optimal sward regrowth and is likely to cause soil compaction, poaching and erosion (e.g. Adnitt } \\
\text { et al. 2007; Doody 2008). }\end{array}$} \\
\hline $\begin{array}{l}\text { (5) } \\
\text { Habitat } \\
\text { impact }\end{array}$ & $\begin{array}{l}\text { Gazing index value assessed for each grazing } \\
\text { area per visit. Score based on maximum } \\
\text { grazing pressure index from any grazing area }\end{array}$ & $\begin{array}{l}\text { Grazing index } \\
=1\end{array}$ & $\begin{array}{l}\text { Grazing index }=0 \\
\text { or } \\
\text { Grazing index }=2\end{array}$ & $\begin{array}{l}\text { Grazing index } \\
=3\end{array}$ \\
\hline
\end{tabular}

per site-visit (accounting for the most detrimental grazing impact from any part of a

This article is protected by copyright. All rights reserved. 
site). Numeric visit-level score (0-2).

Rationalisation/Source: Grazing index indicates grazing impact on habitat where essentially $0=$ no grazing, matted vegetation, no standing crop removed; 1 = light grazing, majority of standing crop not removed; 2 = moderate grazing, majority of standing crop removed; 3 = heavy grazing, all standing crop removed, sward height < 10cm (JNCC 2004). Breeding bird densities and habitat diversity highest where index $=1$, intermediate where index $=0$ or 2 , lowest where index $=3$ (Malpas et al. 2013).

Are sites achieving conservation grazing?

To assess the extent to which the five aspects of conservation grazing are being achieved nationally, and whether this differs between regions with different traditional grazing practices, we ran a modelling analysis where the categorical effect of region was the only predictor. We ran generalised linear mixed models (GLMMs) in R (R Core Team 2017) with site-visit scores for each aspect of conservation grazing as separate response variables. We included the random effect of site in all models to control for repeated site-visits. Model structures and error distributions were as specified in Table 5. For aspect 1 we included all sites in analysis; the score for this aspect was on a binomial scale (Table 2), results indicating the probability that sites that were suitable for grazing had grazing present (i.e. optimal for grazing presence). The achievement of conservation grazing for aspects $2-5$ was only relevant for grazed sites however (Table 2), so for these models we included grazed sites only (Table 5), and used a Conway-Maxwell Poisson error distribution to account for underdispersion (response variable mean > variance; Lynch, Thorson \& Shelton 2014). To assess how well grazed sites are achieving overall, we also analysed the number of grazing aspects scored as optimal as an additional response variable (max score $=4$ ). The level of support for regional differences was assessed by comparing regional models $\left(\mathrm{M}_{\text {region }}\right)$ with national models ( $M_{\text {national; }}$ Table 5) with Information-Theoretic methods based on AIC (Burnham \& Anderson 2002).

This article is protected by copyright. All rights reserved. 
Are AES a successful mechanism for delivering conservation grazing, and to what extent is AES agreement wording fit for purpose?

To compare conservation grazing management on sites experiencing similar environmental characteristics in the presence or absence of AES, we spatially-paired AES and non-AES sites. Paired sites were directly adjacent (where possible), or contiguous, in the same estuary or on the same immediate stretch of coastline if no adjacent sites existed (Fig. S1). In some cases, multiple AES or non-AES sites were contiguous or on the same coastline stretch so these were included in one paired-group for analysis (Table S2). All paired-groups $(n=76)$ contained at least one AES site and at least one non-AES site for direct comparison (total sites in paired-groups $=200$; mean number of $A E S$ sites per group $=1.5$, mean number of Non-AES sites $=1.1$ ). One AES site and 12 non-AES sites could not be paired or grouped with others (no other sites in vicinity, or no AES sites on the whole coastline stretch respectively) so these were excluded from analysis.

\section{Assessing AES as a delivery mechanism}

To test whether scores for the five aspects of grazing (Table 2) differed between AES and Non-AES sites, and whether the type of AES, the inclusion of specific grazing supplements or the agreement age (Table 3) influenced this difference, we ran GLMMs with site-visit scores for each grazing aspect as separate response variables (model structures in Table 6). We also included the number of grazing aspects scored as optimal on grazed sites as an additional response variable to assess how well sites achieved optimal management overall. Models for each response variable contained each of four partially-nested AES effect variables (Table 3) with or without a regional interaction (plus constituent main effects) as

This article is protected by copyright. All rights reserved. 
well as the null model. The effect of region was included to determine if the level of conservation grazing achieved by their AES sites relative to Non-AES sites varied among different statutory agency teams. For aspect 1 , all sites within AES paired-groups were included (Table S2); for aspects 2-5 which are only relevant for grazed sites, we only included sites from paired-groups where at least one AES and one Non-AES site were grazed (i.e. comparing spatially-paired grazed AES and Non-AES sites; Table 6). To directly compare spatially-paired AES and non-AES sites within models, and to control for repeated site-visits, models incorporated the random effect of site nested within paired-group. Support for AES and regional effects was assessed using Information-Theoretic methods based on AIC.

Table 3. Agri-environment scheme (AES) effect variables used in the assessment of AES as a delivery mechanism for conservation grazing.

\begin{tabular}{|c|c|c|}
\hline AES variable & $\begin{array}{l}\text { Type: Levels ( }{ }^{*} \text { reference } \\
\text { category) or Range }\end{array}$ & Hypothesis \\
\hline Site type & $\begin{array}{l}\text { Categorical: Non-AES*, } \\
\text { AES }\end{array}$ & $\begin{array}{l}\text { AES sites expected to attain higher conservation grazing scores if } \\
\text { AES are a successful delivery mechanism. }\end{array}$ \\
\hline AES type & $\begin{array}{l}\text { Categorical: Non-AES*, } \\
\text { CSS, HLS }\end{array}$ & $\begin{array}{l}\text { Different AES may differ in the specificity of conservation grazing } \\
\text { prescribed and therefore the conservation grazing score attained. } \\
\text { CSS = Countryside Stewardship; HLS = Higher Level Stewardship }\end{array}$ \\
\hline Grazing options & $\begin{array}{l}\text { Categorical: Non-AES*, } \\
\text { AES-, AES+ }\end{array}$ & $\begin{array}{l}\text { AES with supplements paid specifically for conservation grazing } \\
\text { management (HP10/HP11/HR1, Table 1) expected to attain a } \\
\text { higher conservation grazing score. AES- = AES without } \\
\text { HP10/HP11/HR1, AES+ = AES with HP10/HP11/HR1 }\end{array}$ \\
\hline Years in AES & Continuous: 0-10 & $\begin{array}{l}\text { Agreement age in 2013: older agreements have had more time to } \\
\text { implement conservation grazing, or younger agreements may be } \\
\text { based on more recent conservation grazing research } \\
\text { recommendations, thereby affecting conservation grazing score. } \\
\text { Years in AES = } 0 \text { (intercept, average score for Non-AES sites), } \\
\text { Years in AES = 1-10 (gradient, score relative to agreement age for } \\
\text { AES sites). }\end{array}$ \\
\hline
\end{tabular}

This article is protected by copyright. All rights reserved. 
Is AES agreement wording fit for purpose?

We examined AES agreement documents for 104 of our 106 AES agreements (two not available) and extracted the wording for management prescriptions associated with saltmarsh management and grazing options (Table 1). Management prescriptions were scored in relation to whether they were specific or not combined with how optimal they were for conservation grazing (Table 4), following criteria in Table 2 and Table S4. Prescription scores were on the same scales and therefore directly comparable with conservation grazing scores defined above.

To assess whether prescription scores were reflected in the delivery of conservation grazing, we compared site-level conservation grazing scores (continuous response variable: mean score per site) with prescription scores for each of the five grazing aspects separately using linear mixed models (LMMs) containing the random effect of region. For grazing presence, prescription score was categorical (levels: 0,1 ), for all other aspects prescription score was continuous (range 0-2). Support for an effect of prescription score was assessed by comparing AIC between models with and without this variable (Table S5 for model structures and outcomes)

This article is protected by copyright. All rights reserved. 
Table 4. Score definitions for the specificity and level of conservation grazing stipulated in agrienvironment scheme management prescriptions for the five aspects of conservation grazing.

Aspect(s) Prescription score and definition

(1) Grazing presence $\quad 0=$ Not specific (aspect not specified in prescriptions)

$1=$ Specific \& Optimal (aspect specified at optimal conservation levels)

Binary score, range $=0-1$

(2) Stock type $\quad 0=$ Not specific (aspect not specified in prescriptions)

(3) Grazing intensity $\quad 1=$ Specific \& Suboptimal/Detrimental (aspect specified but not at optimal levels)

(4) Timing of grazing $2=$ Specific \& Optimal (aspect specified at optimal conservation levels)

(5) Habitat impact Numeric score, range 0-2

\section{Results}

Is conservation grazing being achieved on English saltmarshes?

At a national level there is a high probability that sites suitable for grazing are being grazed (grazing presence; Table 5, Fig. 2a). However, grazed sites scored $<1$ on average for all other aspects of conservation grazing nationally and regionally (Table 5, Fig. 2b), achieving optimal levels for no more than one grazing aspect per site (Fig. 2c). Sites are therefore failing to achieve optimal and in many cases suboptimal levels of conservation grazing. Nationally, sites scored the worst in terms of grazing timing and impact on the habitat. Regional differences in scores were supported for stock type, grazing intensity, grazing timing and habitat impact, but the direction of the regional effect differed, with no region scoring higher than other regions overall, and all regions scoring $<1$ on average for all aspects (Table 5, Fig. 2b).

This article is protected by copyright. All rights reserved. 
Table 5. Results from generalised linear mixed models (GLMMs) assessing the spatial variation in scores for the five aspects of conservation grazing, and the number of aspects scored as optimal on grazed sites, at national $\left(M_{\text {national }}\right)$ and regional ( $\left.\mathrm{M}_{\text {regional }}\right)$ scales. Bold values indicate support for regional differences.

\begin{tabular}{|c|c|c|c|c|c|c|c|c|c|c|}
\hline \multirow[b]{2}{*}{ Response } & \multicolumn{4}{|c|}{$\begin{array}{c}M_{\text {national }} \\
\sim 1+(1 \mid \text { Site })\end{array}$} & \multicolumn{4}{|c|}{$\begin{array}{c}\mathrm{M}_{\text {regional }} \\
\sim \text { Region }+(1 \mid \text { Site })\end{array}$} & \multicolumn{2}{|c|}{$\begin{array}{c}\text { Regional } \\
\text { differences }\end{array}$} \\
\hline & AIC & $\log \operatorname{Lik}(\mathrm{df})$ & w & $\overline{\sigma^{2}}$ & $\mathrm{AIC}$ & $\log \operatorname{Lik}(\mathrm{df})$ & $w$ & $\sigma^{2}$ & $\triangle \mathrm{AIC}$ & ratio \\
\hline (1) Grazing presence score $(0,1)^{a}$ & 839.9 & $-418.0(3)$ & 0.38 & 7.92 & 838.9 & $-415.5(5)$ & 0.62 & 7.54 & 0.95 & 1.6 \\
\hline (2) Stock type score $(0-2)^{b}$ & 1133.3 & $-563.7(3)$ & 0.06 & 0.70 & 1127.8 & $-559.9(5)$ & 0.94 & 0.65 & 5.47 & 15.4 \\
\hline (3) Grazing intensity score $(0-2)^{b}$ & 1076.2 & $-535.1(3)$ & 0.10 & 0.46 & 1071.8 & $-530.9(5)$ & 0.90 & 0.41 & 4.38 & 8.9 \\
\hline (4) Grazing timing score $(0-2)^{b}$ & 594.2 & $-294.0(3)$ & 0.06 & 1.35 & 588.7 & $-289.4(5)$ & 0.94 & 1.21 & 5.46 & 15.3 \\
\hline (5) Habitat impact score $(0-2)^{b}$ & 608.3 & $-301.1(3)$ & 0.00 & 2.18 & 594.4 & $-292.2(5)$ & 1.00 & 2.01 & 13.88 & 1034.3 \\
\hline No. of aspects with optimal score & 965.6 & $-479.8(3)$ & 0.41 & 0.16 & 964.9 & $-477.5(5)$ & 0.59 & 0.15 & 0.70 & 1.4 \\
\hline \multicolumn{11}{|c|}{ 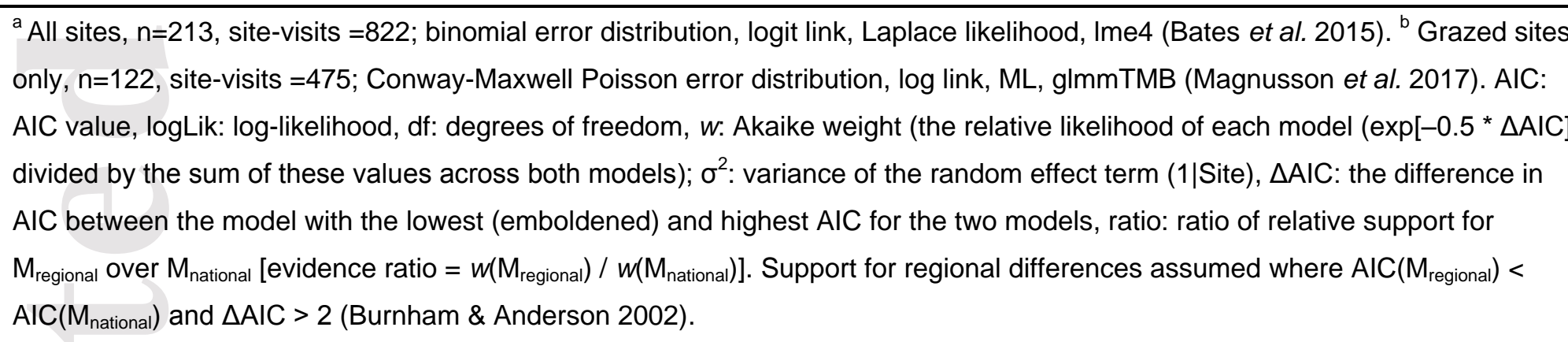 } \\
\hline
\end{tabular}

This article is protected by copyright. All rights reserved. 
(a) Probability of achieving optimal level
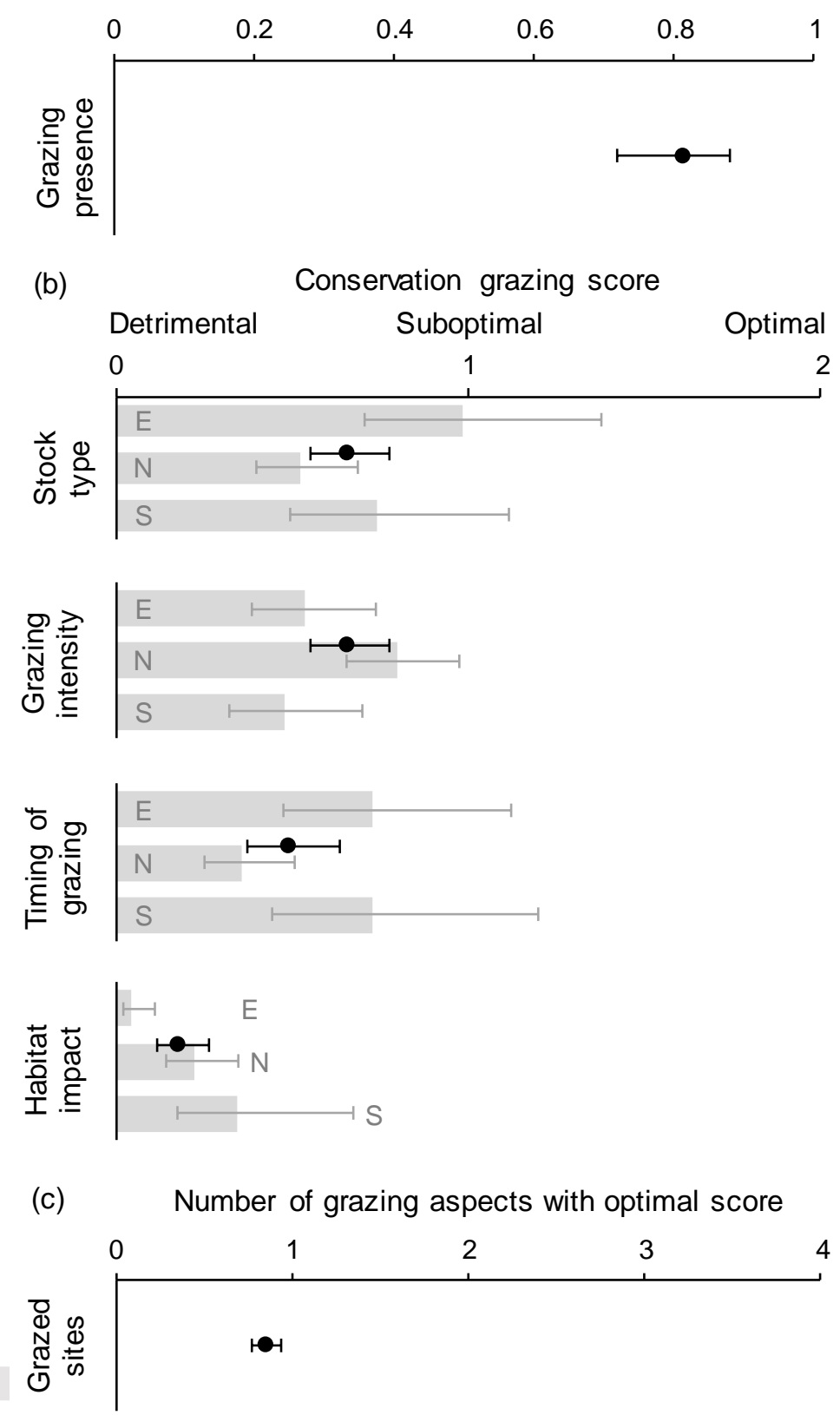

Figure 2. Assessments of conservation grazing on English saltmarshes. Shown are national (point) and regional (bar) mean values estimated by binomial (a) or Conway-Maxwell Poisson ( $b$ and c) GLMMs assessing the probability of achieving an optimal grazing presence score (grazing present on suitable sites) across all sites (a), and on grazed sites the scores for the other aspects of conservation grazing (b) and the number of these aspects achieving optimal scores (c). Regional averages are only shown where regional differences were supported by AIC comparisons $($ East $=E$, Northwest $=\mathrm{N}$, South $=\mathrm{S}$ ). Error bars are 95\% confidence intervals.

This article is protected by copyright. All rights reserved. 
Are AES a successful mechanism for delivering conservation grazing, and to what extent is AES agreement wording fit for purpose?

\section{Assessing AES as a delivery mechanism}

At both the national and regional level, the probability that sites suitable for grazing are being grazed was not influenced by the presence of AES, irrespective of AES type, specific grazing options or agreement age (Table 6). The scores achieved for the other aspects of conservation grazing, and the number of aspects which were scored as optimal, also did not differ between grazed spatially-paired AES and non-AES sites with the exception of grazing intensity on sites in the East, where older AES sites scored substantially higher and approached optimal levels (Table 6, Fig. 3).

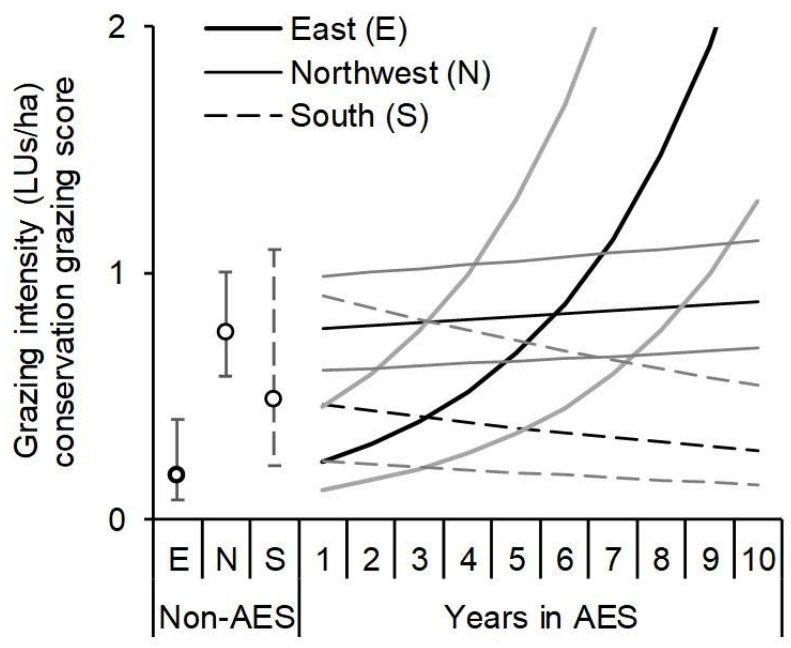

Figure 3. Effects of AES on grazing intensity conservation grazing score on English saltmarshes (Table 6). Points indicate the regional average score for sites without AES agreements (non-AES; years in AES $=0)$, lines $( \pm 95 \% \mathrm{Cls})$ indicate the regional predicted change in score on AES sites with increasing age of AES agreement (years in AES $>0$ ). Error bars are $95 \%$ confidence intervals.

This article is protected by copyright. All rights reserved. 
Table 6. Results from generalised linear mixed models (GLMMs) assessing the regional variation in scores for five aspects of conservation grazing, and the number of aspects scored as optimal on grazed sites (aspects 2-5 only), in relation to AES effects $\left(\sim X=\right.$ AES variables singly, $\sim X^{\star} R=$ their interaction with Region plus constituent main effects and $\sim 1=$ the null model). For each response variable the AIC of the best model (lowest AIC, dark-grey shaded) is reported, with the difference in AIC between the focal model and the best model $(\triangle A I C)$ reported for all other models (models with similar support to the best model $(\triangle \mathrm{AIC}<2)$ are light-grey highlighted (Burnham \& Anderson 2002)). For full model selection tables and top model coefficients see Table S6. Regional interactions could not be run in some cases because of over-parameterisation issues (insufficient variation in response variable for all category combinations; "- " models not run). The final column indicates whether an effect of AES on conservation grazing score was concluded (i.e. the best model included an AES variable and had substantially more support than the null model: $\triangle \mathrm{AIC}<2$ ), with the effect direction in parentheses (positive + in favour of AES sites).

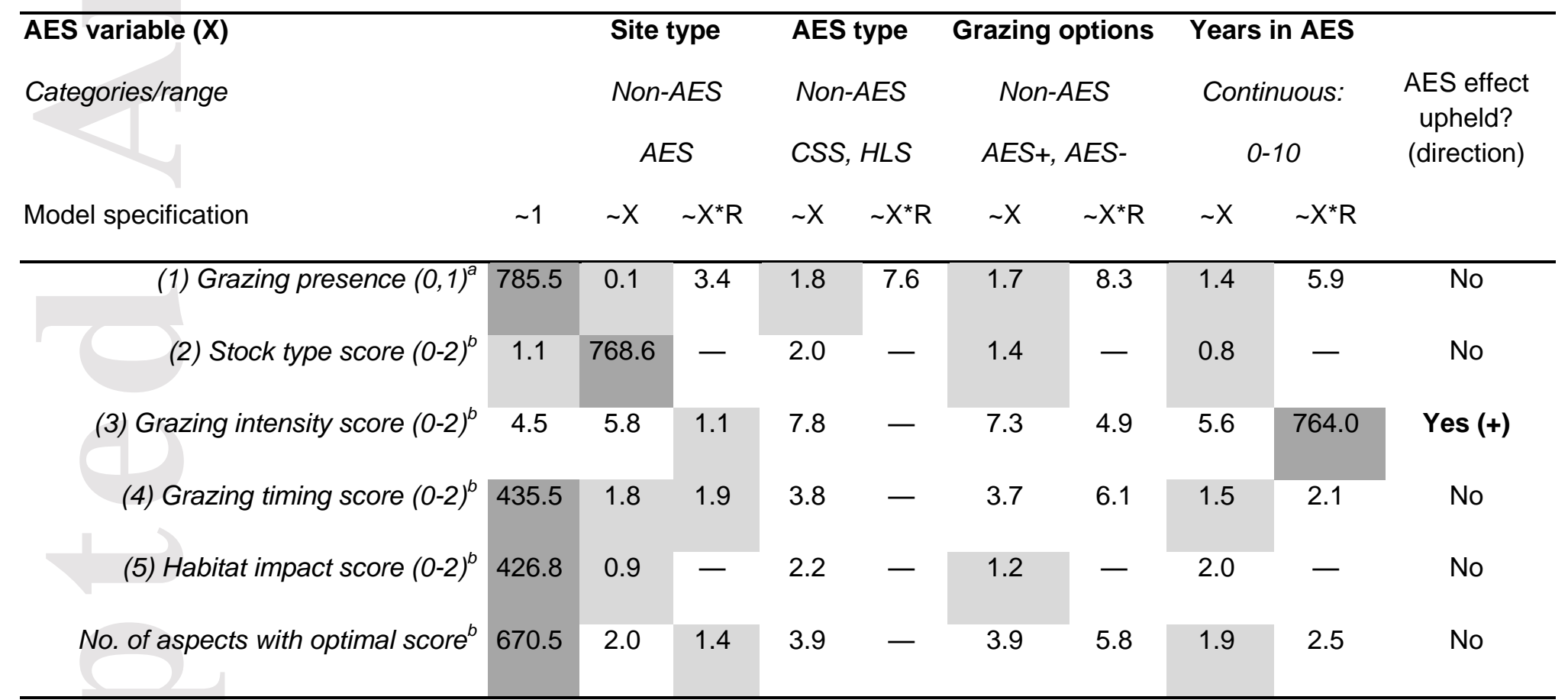

\footnotetext{
${ }^{a}$ All spatially-paired AES/Non-AES sites: paired-groups $=76$, sites $=200$, site-visits $=772$; binomial error distribution, logit link, Laplace likelihood estimation, Ime4 (Bates et al. 2015), optimizer bobyqa (Powell 2009). ${ }^{b}$ Grazed spatially-paired AES/Non-AES sites only: paired-groups $=33$, grazed sites $=90$, site-visits $=347$; Conway-Maxwell Poisson error distribution, log link, Maximum likelihood estimation, glmmTMB (Magnusson et al. 2017).
}

This article is protected by copyright. All rights reserved. 
Is AES agreement wording fit for purpose?

Management prescriptions within AES agreements scored very highly for the presence of grazing at a national and regional level (Fig. 4a). Conservation grazing scores actually achieved by AES sites for this aspect also largely matched their corresponding management prescription scores (conservation grazing score $=1$ where prescription score $=1$ in $80 \%$ of cases), although overall there was no difference in conservation grazing score for either prescription score level for this grazing aspect (Fig. 5a; Table S5).

For conservation grazing aspects relevant for grazed sites, AES agreements also achieved high prescription scores in relation to habitat impact both nationally and regionally, indicating that this aspect of conservation grazing is specified more often at optimal conservation levels within management prescriptions (Fig. 4b). Prescription scores were low for stock type, grazing intensity and grazing timing at both spatial scales however (Fig. 4b). This is reflected in the low total number of grazing aspects with specific and optimal prescription wording (Fig. 4c)

There was a shallow but increasing trend in conservation grazing score in relation to prescription score for stock type and grazing timing, but no or shallow-negative relationships for grazing intensity and habitat impact (Fig. 5, Table S5). No sites achieved optimal conservation grazing (i.e. conservation grazing score $=2$ ) even when prescriptions specified optimal management however (prescription score = 2; Fig. 5) .

This article is protected by copyright. All rights reserved. 

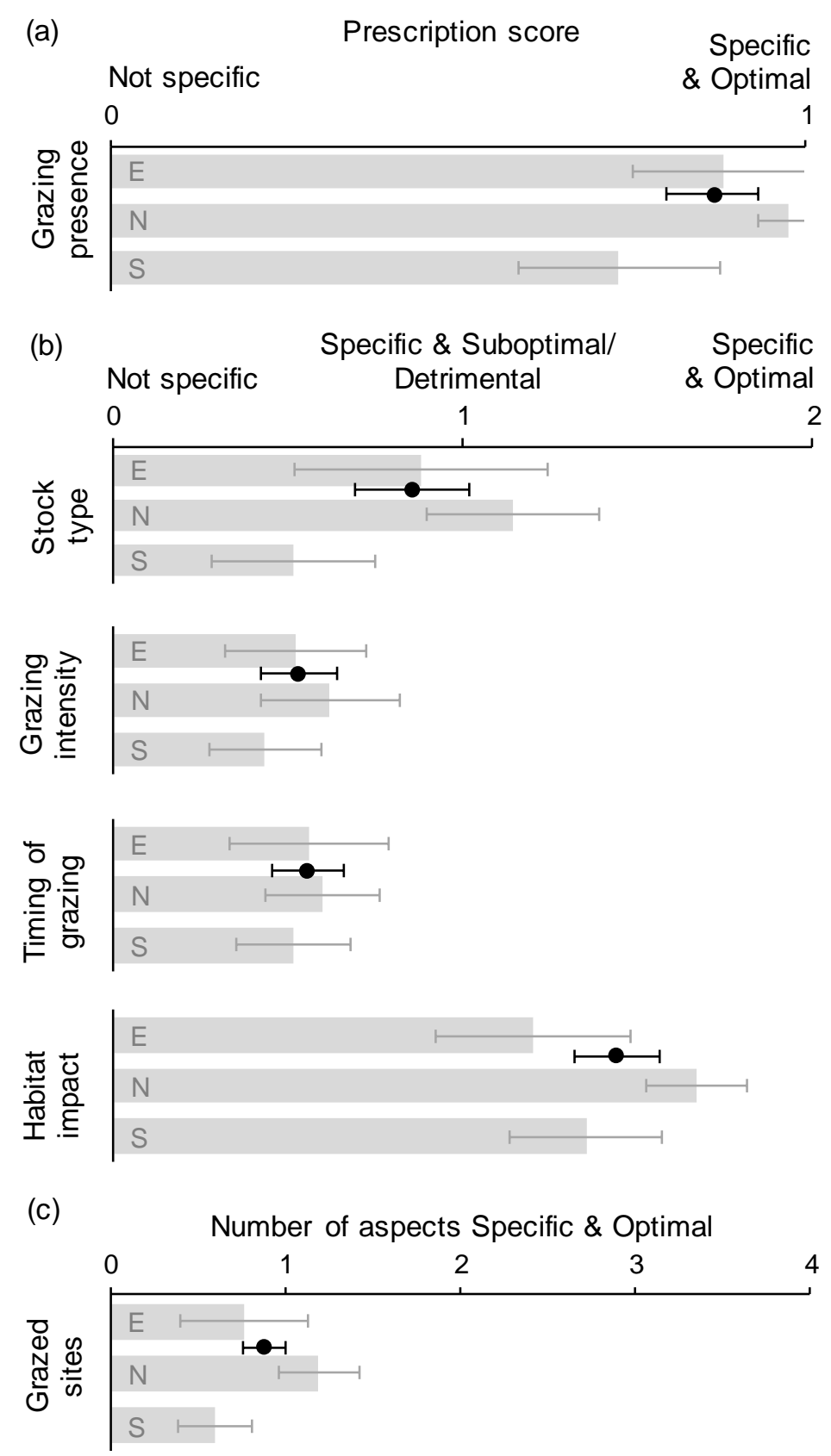

Figure 4. Summary of the agri-environment scheme management prescription scores.

Shown are the mean $\pm 95 \%$ confidence interval national (points) and regional (bars: East $E$, Northwest N, South S) prescription scores for five aspects of conservation grazing (a \& b), and (c) the number of aspects where prescription wording was specific and optimal for the aspects relevant to grazed sites (those shown in b).

This article is protected by copyright. All rights reserved. 

(a) Grazing presence
(b) Stock type
(c) Grazing intensity
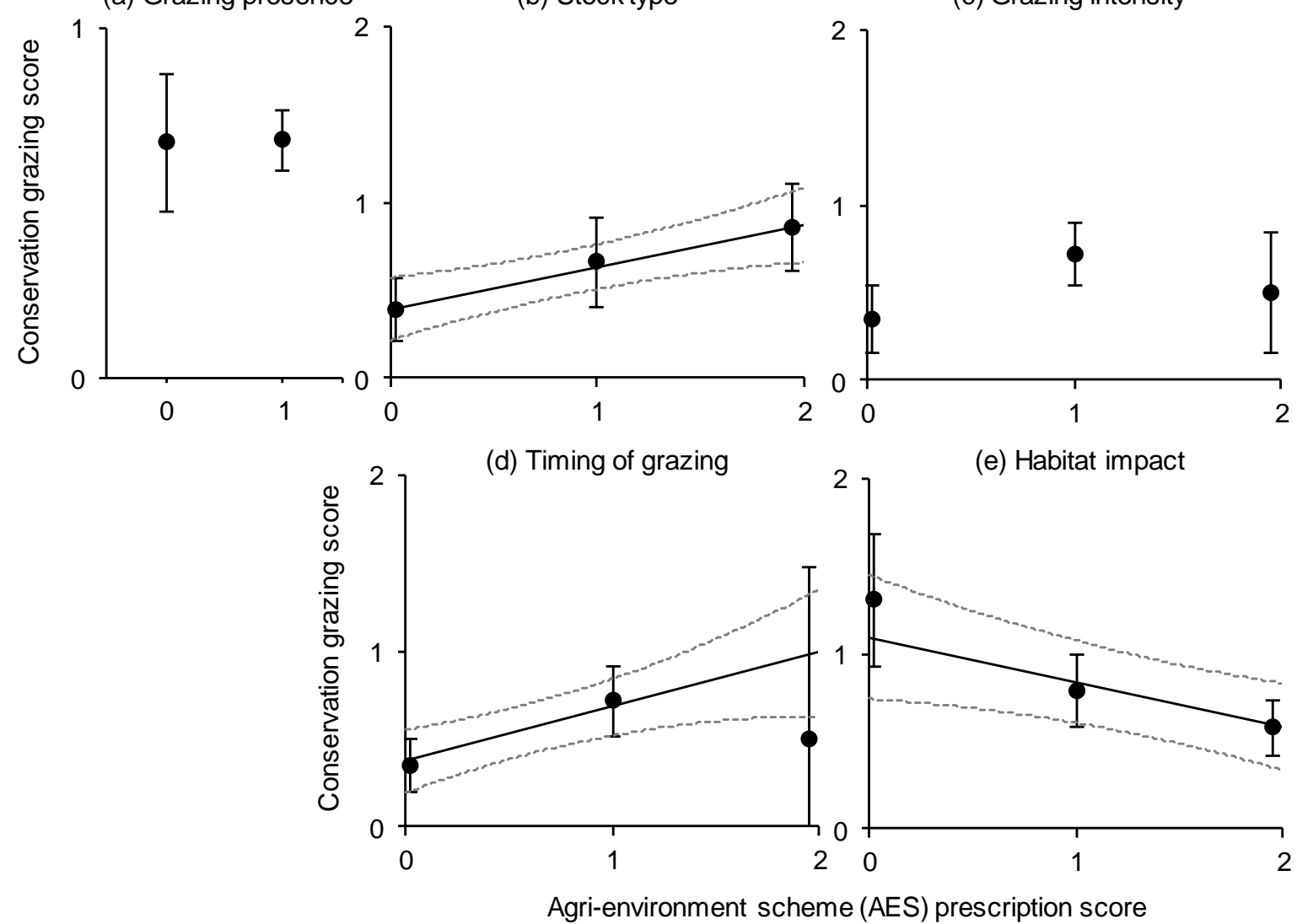

Figure 5. Conservation grazing scores on AES sites in relation to their prescription scores for five aspects of conservation grazing. All points are means $\pm 95 \%$ confidence intervals predicted by LMMs (a) or from raw data at a given prescription score (b-e). For (b-e) lines show the predicted relationships between conservation grazing and prescription scores from LMM models for aspects where this relationship was supported by AIC comparisons (solid = predicted relationship, dotted $=95 \% \mathrm{Cl}$; Table S5) .

This article is protected by copyright. All rights reserved. 


\section{Discussion}

Our results indicate that although most saltmarsh sites in England that are capable of supporting grazing are grazed by livestock, conservation grazing is not being achieved. Grazing is therefore not being conducted by cattle at 'low/moderate' grazing intensity from April or June to October, with variable sward heights and retained standing vegetation crops in the resulting habitat across English sites overall (Table 2; Adnitt et al. 2007; Doody 2008; Mandema et al. 2015; van Klink et al. 2016; Lagendijk et al. 2017; Sharps et al. 2017). At a national level, the timing of grazing and the impact of grazing on the habitat had the lowest scores, indicating that these two aspects of conservation grazing are where management is failing the most. There were regional differences in scores relating to stock type, grazing intensity, grazing timing and habitat impacts, but no region scored higher than others overall. Additionally, we found that sites with AES agreements were no more likely to be grazed than sites without AES, and although AES did marginally influence grazing intensity, the presence of AES did not enable sites to achieve optimal conservation grazing requirements, indicating that $A E S$ in their current form are an ineffective conservation grazing delivery mechanism on saltmarsh.

In temperate regions around the world, grazing by domestic livestock is an important component of the management of a range of grassland habitats (Watkinson \& Ormerod 2001). The end goal of grazing can vary from commercial agriculture to biodiversity conservation but, in natural or semi-natural habitats, grazing often has a dual purpose whereby biodiversity areas require sensitive grazing yet only commercial grazing animals are available for the task. In these situations, payments from agri-environment schemes aim to compensate farmers for loss of income through grazing more sensitively for biodiversity. Here we use a relatively novel approach to assess whether AES delivers grazing that is

This article is protected by copyright. All rights reserved. 
likely to benefit biodiversity conservation, based on key aspects of conservation grazing reviewed from the literature. This approach is novel in its application to grazing management but was adapted from a similar approach used more widely to score habitat suitability for breeding lapwings Vanellus vanellus and to relate those scores to agri-environment management (Smart et al. 2013). We argue that this approach could be more widely adopted in the assessment of the success of any conservation action, not just AES, assuming the specific desired outcomes of management are clear and the success of conservation interventions at achieving those outcomes can be assessed.

The UK supports $\sim 17 \%$ of the saltmarsh designated under Natura 2000 (Doody 2008) but $37 \%$ of saltmarsh priority sites are not achieving the target conservation value under the UK Biodiversity Action Plan (JNCC 2004). Livestock grazing is the main tool by which saltmarsh condition could be improved through direct management intervention, and what constitutes optimal conservation grazing is well-studied on European saltmarshes (we found 26 papers 1972-2017 recommending saltmarsh grazing levels: Table S1). However, our results and those from other parts of Europe where saltmarsh condition is declining, show that saltmarsh conservation grazing is not being achieved (Wolff et al. 2010; Exo et al. 2017; Haynes et al. 2017), so despite frequent exchanges between researchers (Garbutt et al. 2017) this knowledge is not adequately disseminated to policymakers and managers. The issue therefore is not a lack of evidence about how saltmarshes should be managed, but an issue of the translation of evidence into recommendations for hands-on management and in encouraging land managers to implement recommendations when these go against traditional farming practices and economic gain.

The main way in which research findings can be translated into actions while providing an incentive to land managers is through AES, so the overall failure of English AES in

This article is protected by copyright. All rights reserved. 
influencing conservation grazing is concerning, particularly if AES sites are already biased towards those where habitat conditions and land-owner enthusiasm are more conducive to conservation (Kleijn \& Sutherland 2003). We did find some evidence that AES sites improve over time in one region. This is perhaps because older agreements have longer for beneficial management changes to be implemented and take effect or were more prescriptive and provided with better guidance closer to their scheme's start. These findings, both the overall lack of beneficial effects on AES sites and minor positive effects of agreement age are supported by other studies from Europe (e.g. Kleijn et al. 2001; Smart et al. 2013).

The annual cost of saltmarsh and grazing management options in the agreements studied was $£ 543,075$ for 10,218 ha of saltmarsh, equating to over $£ 5$ million spent on saltmarsh management options over the course of 10 years. Livestock grazing is the only active saltmarsh management method available through English AES agreements, but grazing was no more likely on AES sites than non-AES sites, and only half $(51 \%)$ of AES sites were recorded as grazed during our surveys. This implies that many AES sites were paid to maintain saltmarsh by essentially doing nothing, a seemingly uneconomical exercise when $96 \%$ of the sites we surveyed were already protected against damaging actions through UKnational and/or European designations (Sites of Special Scientific Interest, Special Protection Areas, Special Areas of Conservation, Ramsar sites; JNCC 2004). Even if all AES sites had been grazed, the current prescriptions for the grazing management of saltmarsh are clearly not cost effective if the agreements are not delivering the necessary conservation management for this habitat and the species it supports.

This article is protected by copyright. All rights reserved. 
The low specificity of AES prescription wording provides one mechanism through which the failure of AES in influencing saltmarsh grazing management could be explained. Prescription wording scored highly for the presence of grazing on sites that have been traditionally grazed. However, the more major areas of failure were grazing intensity, timing and stock type, where management was either not specific or specified suboptimal conservation levels. Agreement-holders are required to follow these prescriptions strictly, so it is perhaps not surprising that the lack of specificity has resulted in a lack of optimal conservation grazing on the ground. In addition, the restricted nature of livestock grazing for conservation management (i.e. lower stocking rates, restrictions on timing and stock type) introduces practical and economic constraints that are likely to influence the management decisions of land managers. Practical constraints include the availability of grazing animals of the appropriate type, capacity to move animals or to restrict their access in space and time, the logistics and economics of operating smaller herds and ensuring that livestock have access to water and safe areas where they can escape from high tides. Economic constraints are also likely to be important and the restricted nature of conservation grazing will undoubtedly reduce income relative to unrestricted grazing. If $A E S$ payments are not sufficient to remove these economic constraints, then it is likely that grazing patterns will tend more towards commercial rather than conservation goals. The current grazing management on English saltmarshes is therefore likely to reflect land managers attempting to maximise income while operating within the constraints imposed by their AES prescriptions and the practicalities of grazing saltmarshes.

Conversely, if prescription wording could be improved then on-site grazing management is also likely to improve, as where prescriptions were more specific and optimal, sites implemented better conservation management in terms of stock type and timing of grazing. Being the simplest to define, these are perhaps the easiest aspects to translate into on-site management and subsequently enforce. Grazing intensity and habitat condition are aspects

This article is protected by copyright. All rights reserved. 
which are more difficult to quantify and therefore enforce, which may explain the lack of translation into on-site grazing even when prescriptions specify optimal management.

Currently, the prescriptions in each agreement are selected by a statutory-agency regional adviser from a pre-defined set of mandatory and elective phrases. The phrases relating to grazing are all elective, lack detail and make no reference to or suggestions for recommended stock types, grazing intensity or timing (although advisers may add additional details if they wish). Agreement wording could therefore be greatly improved if grazingrelated prescriptions were made mandatory for livestock-grazed sites, and provided specific guidance in terms of stock type, grazing intensity and timing. Improved translation of saltmarsh research findings into recommendations for actual management would be of direct benefit here, as would detailed consultations with researchers and land managers by policymakers when developing new schemes to ensure the incorporation of relevant and recent evidence for beneficial management (Barnett 2007).

Saltmarsh sites in this study were not achieving conservation grazing, and AES sites were grazed no differently than non-AES sites. However, AES are still the only mechanism through which conservation grazing can be implemented nationally on saltmarshes, and the large proportion of English saltmarsh already under AES presents a unique opportunity for comprehensive landscape-scale intervention if these AES could be improved to deliver the necessary outcomes (Smart et al. 2013). We propose that the five aspects of saltmarsh conservation grazing be incorporated into AES prescriptions in future to dramatically increase the specificity of AES agreements and their utility for conservation management (Appendix S1). Additionally, a more detailed and reliable system of auditing would be beneficial (www.gov.uk; JNCC 2004), to ensure that management activities take place to the necessary standard prior to payments. Moving to a results-based scheme where payments

This article is protected by copyright. All rights reserved. 
are made on desirable outcomes rather than on evidence of management may also improve the overall conservation value and economic efficiency of saltmarsh AES options

(Armsworth et al. 2012; Hanley et al. 2012; Hasund 2013; Keenleyside et al. 2014).

Policymakers, researchers and land managers need to work together to ensure that AES effectiveness is improved, particularly through better translation of conservation guidelines into AES, detailed consultations with land managers and researchers when designing new schemes, and the increased specificity of prescription wording with detailed rationales to improve mutual understanding of particular grazing management between agreement advisers and managers. In habitats where this process has already been undertaken (e.g. for lowland wet grassland in the UK), bespoke AES in combination with site protection are much more successful in delivering conservation outcomes (e.g. improved breeding habitat for wading birds, Smart et al. 2014). A similar tailoring process on saltmarsh is likely to benefit multiple species and processes within the saltmarsh ecosystem.

This article is protected by copyright. All rights reserved. 


\section{Authors' contributions}

Study conceived by LRM \& JS; designed by LRM. Data acquired by AF, NG, CV \& LRM. Analyses conducted and paper written by LRM; JS provided revisions. All authors approved and are accountable for the final manuscript.

\section{Acknowledgements}

This study was funded by the RSPB. Many thanks to landowners who allowed site access, and Allan Drewitt and regional Natural England staff who provided assistance in arranging this. AES agreement documents, spatial data and locations of management options were provided under Open UK Government License for public sector information by Natural England in 2013. Jenny Gill provided comments that improved the manuscript.

\section{Data accessibility}

Data available via the Dryad Digital Repository https://doi:10.5061/dryad.p3g44gh (Mason et al. 2019)

\section{Supporting information}

Figure S1. Site location maps

Table S1. Conservation grazing rates

Table S2. Study site information

Table S3. Livestock Unit conversions

This article is protected by copyright. All rights reserved. 
Table S4. Prescription scoring

Table S5. Prescription analysis results

Table S6. Model selection tables

Appendix S1. Recommendations for prescription wording

This article is protected by copyright. All rights reserved. 


\section{References}

Adnitt, C., Brew, D., Cottle, R., Hardwick, M., John, S., Leggett, D., McNulty, S., Meakins, N. \& Staniland, R. (2007) Saltmarsh management manual. Environment Agency, DEFRA, Bristol, UK.

Armsworth, P.R., Acs, S., Dallimer, M., Gaston, K.J., Hanley, N. \& Wilson, P. (2012) The cost of policy simplification in conservation incentive programs. Ecology Letters, 15, 406-414.

Ausden, M. (2007) Habitat management for conservation: a handbook of techniques. Oxford University Press.

Barbier, E.B., Hacker, S.D., Kennedy, C., Koch, E.W., Stier, A.C. \& Silliman, B.R. (2011) The value of estuarine and coastal ecosystem services. Ecological Monographs, 81, 169193.

Barnett, A. (2007) Agri-environmental policy: a European overview. Aspects of Applied Biology, 81, 1-6.

Batáry, P., Dicks, L.V., Kleijn, D. \& Sutherland, W.J. (2015) The role of agri-environment schemes in conservation and environmental management. Conservation Biology, 29, 1006-1016.

Bates, D., Maechler, M., Bolker, B. \& Walker, S. (2015) Fitting Linear Mixed-Effects Models Using Ime4. Journal of Statistical Software, 67, 1-48.

Boorman, L.A. (2003) Saltmarsh review: An overview of coastal saltmarshes, their dynamic and sensitivity characteristics for conservation and management. JNCC Report, No. 334.

This article is protected by copyright. All rights reserved. 
Burd, F. (1989) The saltmarsh survey of Great Britain. Research and Survey in Nature Conservation, No. 17. Nature Conservancy Council, Peterborough, UK.

Burnham, K.P. \& Anderson, D.R. (2002) Model selection and multi-model inference: $A$ practical information-theoretic approach. Springer-Verlag, Berlin.

Chatters, C. (2004) Grazing domestic animals on British saltmarshes. British wildlife, 15, $392-400$.

Clausen, K.K., Stjernholm, M. \& Clausen, P. (2013) Grazing management can counteract the impacts of climate change-induced sea level rise on salt marsh-dependent waterbirds. Journal of Applied Ecology, 50, 528-537.

Davidson, K.E., Fowler, M.S., Skov, M.W., Doerr, S.H., Beaumont, N. \& Griffin, J.N. (2017) Livestock grazing alters multiple ecosystem properties and services in salt marshes: a meta-analysis. Journal of Applied Ecology, 54, 1395-1405.

DEFRA (2004) The Countryside Stewardship Scheme (CSS) 2004: Information and how to apply. DEFRA (Department for Environment, Food and Rural Affairs), UK.

DEFRA (2010) Definition of Terms used in Farm Business Management. LU conversion table located in Appendix 1 p37. Available at:

http://webarchive.nationalarchives.gov.uk/20130402193300/http://archive.defra.gov.u k/foodfarm/farmmanage/advice/documents/def-of-terms.pdf.

Dijkema, K.S. (1990) Salt and brackish marshes around the Baltic Sea and adjacent parts of the North Sea: Their vegetation and management. Biological Conservation, 51, 191 209.

Doody, J.P. (2004) Coastal Squeeze - an historical perspective. Journal of Coastal Conservation, 10, 129-138.

This article is protected by copyright. All rights reserved. 
Doody, J.P. (2007) Saltmarsh conservation, management and restoration. Springer Science \& Business Media.

Doody, J.P. (2008) Management of Natura 2000 habitats. 1330 Atlantic salt meadows (Glauco-Puccinellietalia maritimae). European Commission.

Environment Agency (2015) Saltmarsh Extents. Available from https://data.gov.uk/dataset/saltmarsh-extents1 (accessed June 2017).

European Environment Agency (2009) Habitats Directive Article 17 Reporting: 1330-Atlantic salt meadows (Glauco-Puccinellietalia maritima). http://ec.europa.eu/environment/nature/knowledge/rep_habitats/ (accessed April 2018).

Exo, K.-M., Wellbrock, A.H., Sondermann, J. \& Maier, M. (2017) Assessing the impact of mowing on Common Redshanks Tringa totanus breeding on saltmarshes: lessons for conservation management. Bird Conservation International, 1-14.

FitzGerald, D.M., Fenster, M.S., Argow, B.A. \& Buynevich, I.V. (2008) Coastal impacts due to sea-level rise. Annu. Rev. Earth Planet. Sci., 36, 601-647.

Garbutt, A., de Groot, A., Smit, C. \& Pétillon, J. (2017) European salt marshes: ecology and conservation in a changing world. Journal of Coastal Conservation, 21, 405-408.

Gedan, K.B., Silliman, B.R. \& Bertness, M.D. (2009) Centuries of human-driven change in salt marsh ecosystems. Annual Review of Marine Science, 1, 117-141.

Hanley, N., Banerjee, S., Lennox, G.D. \& Armsworth, P.R. (2012) How should we incentivize private landowners to 'produce' more biodiversity? Oxford Review of Economic Policy, 28, 93-113.

Hasund, K.P. (2013) Indicator-based agri-environmental payments: A payment-by-result model for public goods with a Swedish application. Land use policy, 30, 223-233.

This article is protected by copyright. All rights reserved. 
Haynes, T.A., Angus, S., Scanlan, C. \& Bhatti, N. (2017) Developing a saltmarsh monitoring methodology to meet multiple policy and management objectives in Scotland. Journal of Coastal Conservation, 21, 445-452.

Hill, M.I. (1988) Saltmarsh vegetation of the Wash: An assessment of change from 1971 to 1985. Research and Survey in Nature Conservation, No. 13. Nature Conservancy Council, Peterborough.

Hughes, R.G. (2004) Climate change and loss of saltmarshes: consequences for birds. Ibis, $146,21-28$.

JNCC (2004) Common Standards Monitoring Guidance for Saltmarsh Habitats.

Jones, L., Angus, S., Cooper, A., Doody, P., Everard, M., Garbutt, A., Gilchrist, P., Hansom, J., Nicholls, R., Pye, K., Ravenscroft, N., Rees, S., Rhind, P. \& Whitehouse, A. (2011) Coastal Margins. UK National Ecosystem Assessment Technical Report, pp. 411-615. UNEP-WCMC, Cambridge.

Keenleyside, C., Radley, G., Tucker, G., Underwood, E., Hart, K., Allen, B. \& Menadue, H. (2014) Results-based payments for biodiversity guidance handbook: Designing and implementing results-based agri-environment schemes 2014-2020. Prepared for the European Commission, DG Environment, Contract ENV.B.2/ETU/2013/0046, Institute for European Environmental Policy, London.

Kleijn, D., Berendse, F., Smit, R. \& Gilissen, N. (2001) Agri-environment schemes do not effectively protect biodiversity in Dutch agricultural landscapes. Nature, 413, 723725.

Kleijn, D. \& Sutherland, W.J. (2003) How effective are European agri-environment schemes in conserving and promoting biodiversity? Journal of Applied Ecology, 40, 947-969.

This article is protected by copyright. All rights reserved. 
Lagendijk, D.D.G., Howison, R.A., Esselink, P., Ubels, R. \& Smit, C. (2017) Rotation grazing as a conservation management tool: Vegetation changes after six years of application in a salt marsh ecosystem. Agriculture, Ecosystems \& Environment, 246, 361-366.

Lynch, H.J., Thorson, J.T. \& Shelton, A.O. (2014) Dealing with under-and over-dispersed count data in life history, spatial, and community ecology. Ecology, 95, 3173-3180.

Magnusson, A., Skaug, H.J., Nielsen, A., Berg, C.W., Kristensen, K., Maechler, M., van Bentham, K.J., Bolker, B.M. \& Brooks, M.E. (2017) glmmTMB: Generalized Linear Mixed Models using Template Model Builder. R package version 0.1.3. https://github.com/glmmTMB.

Malpas, L.R., Smart, J., Drewitt, A.L., Sharps, E. \& Garbutt, A. (2013) Continued declines of Redshank Tringa totanus breeding on saltmarsh in Great Britain: is there a solution to this conservation problem? Bird Study, 60, 370-383.

Mandema, F.S., Tinbergen, J.M., Ens, B.J., Koffijberg, K., Dijkema, K.S. \& Bakker, J.P. (2015) Moderate livestock grazing of salt, and brackish marshes benefits breeding birds along the mainland coast of the Wadden Sea. The Wilson Journal of Ornithology, 127, 467-476.

Mason, L.R., Feather, A., Godden, N., Vreugdenhil, C.C. \& Smart, J. (2019) Data from: Are agri-environment schemes successful in delivering conservation grazing management on saltmarsh? Dryad Digital Repository. https://doi:10.5061/dryad.p3g44gh

McOwen, C.J., Weatherdon, L.V., Bochove, J.-W.V., Sullivan, E., Blyth, S., Zockler, C., Stanwell-Smith, D., Kingston, N., Martin, C.S., Spalding, M. \& Fletcher, S. (2017) A global map of saltmarshes. Biodiversity Data Journal, e11764.

This article is protected by copyright. All rights reserved. 
Natural England (2013) Higher Level Stewardship: Environmental Stewardship handbook. Fourth Edition. Natural England, UK.

Norris, K., Brindley, E., Cook, T., Babbs, S., Forster Brown, C. \& Yaxley, R. (1998) Is the density of redshank Tringa totanus nesting on saltmarshes in Great Britain declining due to changes in grazing management? Journal of Applied Ecology, 35, 621-634.

Norris, K., Cook, T., O'Dowd, B. \& Durdin, C. (1997) The density of redshank Tringa totanus breeding on the salt-marshes of the Wash in relation to habitat and its grazing management. Journal of Applied Ecology, 34, 999-1013.

Phelan, N., Shaw, A. \& Baylis, A. (2011) The extent of saltmarsh in England and Wales: 2006-2009. Environment Agency, Bristol.

Powell, M.J.D. (2009) The BOBYQA algorithm for bound constrained optimization without derivatives. Cambridge NA Report NA2009/06, University of Cambridge, Cambridge.

R Core Team (2017) R: A language and environment for statistical computing, version 3.4.1. R Foundation for Statistical Computing, URL https://www.R-project.org, Vienna, Austria.

Schekkerman, H., Teunissen, W. \& Oosterveld, E. (2008) The effect of 'mosaic management' on the demography of black-tailed godwit Limosa limosa on farmland. Journal of Applied Ecology, 45, 1067-1075.

Sharps, E., Smart, J., Mason, L.R., Jones, K., Skov, M.W., Garbutt, A. \& Hiddink, J.G. (2017) Nest trampling and ground nesting birds: quantifying temporal and spatial overlap between cattle activity and breeding Redshank. Ecology and Evolution, 7, $6622-6633$.

This article is protected by copyright. All rights reserved. 
Smart, J., Bolton, M., Hunter, F., Quayle, H., Thomas, G. \& Gregory, R.D. (2013) Managing uplands for biodiversity: Do agri-environment schemes deliver benefits for breeding lapwing Vanellus vanellus? Journal of Applied Ecology, 50, 794-804.

Smart, J., Wotton, S.R., Dillon, I.A., Cooke, A.I., Diack, I., Drewitt, A.L., Grice, P.V. \& Gregory, R.D. (2014) Synergies between site protection and agri-environment schemes for the conservation of waders on lowland wet grasslands. Ibis, 156, 576590.

UNEP (2006) Marine and coastal ecosystems and human wellbeing: A synthesis report based on the findings of the Millennium Ecosystem Assessment. (ed. U.U.N.E. Programme)). Nairobi, Kenya.

van Klink, R., Nolte, S., Mandema, F.S., Lagendijk, D.G., WallisDeVries, M.F., Bakker, J.P., Esselink, P. \& Smit, C. (2016) Effects of grazing management on biodiversity across trophic levels-The importance of livestock species and stocking density in salt marshes. Agriculture, Ecosystems \& Environment, 235, 329-339.

Watkinson, A. \& Ormerod, S. (2001) Grasslands, grazing and biodiversity: editors' introduction. Journal of Applied Ecology, 38, 233-237.

Wolff, W.J., Bakker, J.P., Laursen, K. \& Reise, K. (2010) The Wadden Sea Quality Status Report - Synthesis Report 2010. Wadden Sea Ecosystem, No. 29. Common Wadden Sea Secretariat, Wilhemshaven, Germany.

This article is protected by copyright. All rights reserved. 